\title{
Just Transition at the Intersection of Labour and Climate Justice Movements: Lessons from the Portuguese Climate Jobs Campaign
}

\author{
Chrislain Eric Kenfack, University of Alberta, Canada
}

\begin{abstract}
In the current context of climate change and its accompanying adverse effects on natural, human and social systems, the imperative of transitioning to low- and preferably post-carbon societies has become a non-negotiable reality if we want to avoid reaching the point of no return in terms of environmental and climate catastrophe. Such a transition requires that the interests and needs of workers and their communities be taken into consideration to make sure they do not bear the heaviest part of the burden in terms of loss of jobs and means of survival, and that they are prepared to face the new, post-carbon labour environment. The concept of Just Transition was coined to describe both the socio-political project put forward by trade unions in response to climate change, and the recognition by climate activists that the livelihoods and security of workers and their communities must be ensured during the transition to a post-carbon society. However, just transition movements are divided between two quite different orientations, which are labelled "affirmative" and "transformative." On the one hand, affirmative just transition advocates envisage a transition within the current political-economic system. Transformative just transition activists, on the other hand, envisage a post-capitalist transition. This article, drawing upon an extensive case study of the Portuguese climate jobs campaign, goes beyond showing how these orientations shape the positions taken by union and climate activists. The article also analyses how the conflicts and cooperation between these key actors can shed light on the possibilities and/or limitations of just transition as a framework for the collective action needed to achieve rapid, deep decarbonisation of economies in the Global North context.
\end{abstract}

\section{KEY WORDS}

climate change; just transition; labour environmentalism; climate jobs; climate justice; climate activism

\section{Introduction}

Climate change is doubtlessly one of the most important and pressing challenges faced by the international community, and global warming is "happening faster than predicted, taking us rapidly closer to a 2 per cent increase in planetary temperatures" (Webster, 2018: 234). Addressing the unabated rise in greenhouse gas (GHG) emissions causing this rise in temperatures as well as the resulting climate change and its negative effects on environmental, human and social systems remains a critical challenge for the global community if we want to save our planet and our living environment from catastrophe. Coupled to that climate crisis, "it is widely acknowledged that the closing decades of the twentieth century, and the early decades of the twenty-first century, have

Global Labour Journal, 2019, 10(3), Page 224 
been marked by growing economic insecurity across the globe" (Paret, 2016: 111). Such a situation, as Paret suggests, worsened the already existing labour-related crises around the world and led to the further development of a precariat "consisting of those who lack seven different forms of security - labour market security, employment security, job security, work security, skill reproduction security, income security and representation security" (Paret, 2016: 112). Faced with that twofold crisis, world leaders have been struggling, with limited success, to put in place effective, efficient and integrative public policies and actions to ensure that our planet is protected and that, in the process, economic growth and development are not jeopardised.

Faced with such limited results and the continued threats of environmental degradation, in the 1990s trade unionists started developing "just transition as a program of support for workers who lost their jobs due to environmental protection policies [as well as the environmental crisis itself]" (Just Transition Centre, 2017: 2). Over time, trade unions and other social movements have broadened the dimensions of just transition (JT) to accommodate efforts "to plan for and invest in a transition to environmentally and socially sustainable jobs, sectors and economies" (Just Transition Centre, 2017: 3). As concerns about global warming grew, unions and their partners, mostly climate justice movements (CJMs), "began to tie just transition specifically to action on climate change", with a focus on the protection and safeguarding of workers' interests, livelihoods and jobs during the transition to a post-carbon economy (Just Transition Centre, 2017: 3). Nevertheless, such articulations between labour and climate justice concerns in the pursuance of a just transition to a low/post-carbon era are subjected to an important divide between defenders of the "affirmative" approach and those who espouse a "transformative" approach. The former, in the nutshell, postulate an ecological transition within a reformed version of the current capitalist model, and the latter postulate an ecological transition in the context of a completely post-capitalist society. Those internal divisions within the just transition project will be instrumental in analysing the deployment of the Portuguese campaign, and rendering an account of its internal conflictual logics. In fact, the emergence of climate jobs campaigns in general, and in particular the Portuguese campaign that is analysed in this article, is in line with the JT project. Campaigners, conscious that "labour power can be used in specific historical phases to significantly alter ... societal structures" (Schmalz, Ludwig and Webster, 2018: 115-16), articulate their climate justice struggles around labour justice ideals. In other words, to paraphrase Arolowo (2015), they seek to channel unemployment into climate policies not only at the global, but also at the national and sub-national levels.

Although the Portuguese campaign cannot be isolated from the global context and from other similar campaigns, it is nevertheless important to mention that the specificity of the Portuguese situation, coupled with the specificity of its climate jobs campaign, mostly led by climate justice activists with a very limited involvement of trade unions and labour movements, accounts for its uniqueness. Such uniqueness calls for a detailed and exclusively dedicated analysis of the Portuguese case in light of the divide between affirmative and transformative versions of a just transition. This article therefore argues that the JT divide between affirmative and transformative approaches is mirrored in the Portuguese climate jobs campaign, and is reflected in the divide between the unionists and the non-union activists involved in the campaign. Nevertheless, campaigners have been struggling to overcome such a divide. The contribution of this article, therefore, goes beyond demonstrating how the JT divide maps onto the division between the two key types of actors - unions and climate activists - to analyse how the conflicts and cooperation between those two categories of actors can shed light on the possibilities and/or limitations of the just transition as a framework for political action.

The Portuguese campaign was launched by a consortium made up of four categories of actors: 
1) climate justice movements such as Climáximo in Lisbon (initiator of the campaign) and Colectivo Clíma in Porto; 2) trade unions such as the General Confederation of Portuguese Workers (Confederação Geral dos Trabalhadores Portugueses, CGTP); 3) labour movements such as the Association for the Fight against Precarious Work (Precários Inflexíveis); and 4) environmental NGOs like the national Environmental Action and Intervention Group (Grupo de Ação e Intervenção Ambiental, GAIA). As defended by Portuguese campaigners, the just transition movement has a double objective. First, it aims to ensure that the current carbon-intensive economy is turned into a low- and possibly a zero-carbon economy. This arises from the conviction that "the shift to a low carbon economy will mean massive changes in the way we produce goods and services, in travel and transport, and in the pattern of future investment" (Trades Union Congress, 2008: 36). The second objective is to ensure labour, social and environmental justice by giving a great importance to the redistribution of climate burdens and benefits, the well-being of workers and the creation of secure and sustainable climate jobs, the participation of all stakeholders in decision-making processes, and government backup to make sure the interests of capital do not prevail over the well-being of society in general and of workers in particular. In their attempts "to create green and decent jobs, transform and improve traditional ones, and include democracy and social justice in environmental decision-making processes" (ITUC, 2009: 10), "workers, employers and government are active and collaborative partners in developing plans for transition and transformation that simultaneously consider environment, social justice and poverty alleviation" (Just Transition Centre, 2017: 4). It is therefore with the aim of pushing authorities to put in place climate policies that secure the creation of clean jobs while protecting workers and their communities that the Portuguese campaign was launched.

To gather the necessary data for this research, I used the extended case method, a methodological approach initially developed by anthropologists Max Gluckman and Jaap van Velsen in the late 1950s and early 1960s. The extended case method is fundamentally built upon the direct involvement of researchers in the milieu, life and activities of their research object (Van Velsen, 1967; Burawoy, 1998). This research is therefore the result of the ethnographic materials gathered during my direct involvement and participation in the activities of the Portuguese campaign between September 2015 and May 2017, supported by seven semi-structured interviews with key informants coming from organisations participating in the campaign; those key informants were selected because they were official representatives of their respective organisations on the organising committee of the campaign. Their selection was not based on gender, age or occupation, but on their representative roles in the preparation and implementation of the campaign. It is important to mention that I did not approach my object of study from an outer perspective. As a climate justice activist and member of Climáximo, I was at the same time fully involved and part of my object of study. Nevertheless, as a researcher, I was fully aware of the critiques that can be addressed to my methodological approach in terms of objectivity because of that personal involvement. To counterbalance those possible critiques, I backed myself off with the "standpoint" approach and, going beyond the understanding of objectivity as neutrality, I built my research on "strong objectivity" by being self-critical of my own subjectivity as a participant-researcher, relying only on scientifically valid arguments and facts based on a multi-source qualitative evaluation. In the methodological approach that I adopted, the position of the observer is a crucial issue (Gobo, 2001). Here, "the social location is very close to epistemic position ... [in the sense that] social locations not only vary from an epistemological point of view, but also and above all because some social locations offer the potential to be more epistemically reliable than others" (Grasswick., 2006: 7). That is why Harding (1995) argues that, through its social location, the standpoint approach offers an incredibly effective opportunity for the production of sound knowledge about 
marginalised groups, understood in this sense as groups that do not necessarily participate in decision-making processes. The social locations from where I carried out this research were therefore those of the climate marginalised and of the climate activists. It is from this perspective that my personal involvement with my object of study, instead of being a sign of methodological weakness, is the very guarantor of the scientific viability and strong objectivity of my arguments.

This article is organised around three main parts. Part one focuses on a short journey through the concept of just transition as a broader framework within which the Portuguese campaign is situated. Part two points out some limits of JT, whereas part three analyses the Portuguese campaign in light of the divide between affirmative and transformative versions of JT.

\section{Just Transition: A Short Journey through the Concept}

The term just transition was coined by Californian activists seeking to improve relations with workers in industries affected by environmental degradation. The original organisation behind the call was the Just Transition Alliance, founded in 1997. However, as a concept, its break-through moment came when the Canadian Labour Congress (CLC) released its 2000 report entitled Just Transition for Workers during Environmental Change. This report gave the term a solid basis within the labour movement (O'Driscoll, 2011). According to the CLC report, just transition is a safeguard that

...provides a measure of workers' participation and control over ... [their] own future. It is a building block for a sustainable economy, one essential element in a progressive environmental policy. ... It is about fairness and environmental justice. It is about quality employment in an economy based on sustainable production and infrastructure. It is about communities as the focus of Just Transition programs - communities as centres of diverse, labour-intensive industries, with a strong public sector to support them. It is, above all, about alternative employment in a sustainable economy (Canadian Labour Congress, 2000: 3).

It is in this context that the concept of just transition emerged, to refer to a transition from an unfair, neo-liberal economy and its high-carbon modes of production and consumption to a fairer, low-carbon economy. The concept was therefore adopted in other contexts and in 2006 was officially endorsed by the government of Argentina as part of its negotiation strategy within the United Nations Framework Convention on Climate Change (UNFCCC) (Barbier, 2010; Roberts, 2010).

In fact, the contrast between the urgent need for action in response to the current global warming situation and the inability of governments to provide sustainable unanimous solutions reveals the need to implement enhanced mechanisms to influence climate decision-making processes. It is in this regard that, at the international level, the International Labour Organization (ILO) and the International Trade Union Confederation (ITUC) have been instrumental in pushing the JT agenda. In the context of global climate negotiations in particular, "the UN's ILO has been arguably most active in promoting this agenda" (Barca, 2015: 393). Since ITUC's creation in 2006 from the merger of the International Confederation of Free Trade Unions (ICFTU) and the World Confederation of Labour (WCL), as Barca (2015) demonstrates, the Confederation created a department in charge of formulating its official position on climate issues. Since then, this department has played an important role in pushing forward the JT agenda, both within the confederation and as part of its official position and strategy in the global climate debates. The JT strategy, as defended by those organisations, recognises that support for environmental policies is 
conditional on a fair distribution of the costs and benefits of those policies across the economy, and on the creation of opportunities for active engagement of those affected in determining their future well-being and that of their families. In short it can be said that "the idea of the just transition has roots in the labour movement and its efforts to connect environmental sustainability with the imperatives of decent work and social inclusion” (Robins, Brunsting and Wood, 2018: 8). It is a tool that trade unions share with the international community in its struggle against environmental degradation and global warming (ITUC, 2009). It is a mechanism that aims to promote sustainable development that is socially just, environmentally friendly and economically efficient, and that emphasises governance and good management in order to provide decent life to millions of people (Olsen, 2010).

To reach its goals, the notion of a just transition is built upon four basic principles. The first principle refers to environmental protections and sustainable development that promote an "integrated approach to sustainable development through a JT where social progress, environmental protection and economic needs are brought into a framework of democratic governance, where labour and other human rights are respected and gender equality achieved" (ITUC 2010: 1). Such an equation of reconciling environmental protection and sustainable development seems difficult to solve, especially in the current capitalist development model which is highly dependent on fossil fuel (UNFCCC, 2009). The second principle deals with inclusive participatory processes "involving employee representatives, such as trade unions, in the planning of environmental measures as ... one way to make better use of employees as drivers of environmental change." (Trades Union Congress, 2008: 4). The third principle requires government leadership in the development of climate friendly and sustainable clean jobs. In this regard,

...it will take State power and public investment to build the infrastructures of a renewable-energy economy. Such projects should be promoted as ways of bringing cheaper and inexhaustible energy from the sun and wind to economically struggling working people, and creating good jobs doing socially useful work (Huber, 2016: n.p.).

Such investments should be done following a large and inclusive social consultation, so as to allow all the stakeholders and social partners to get involved in the process. In fact, according to Bill et al. (2008: 5), a just transition "requires government intervention and community partnerships to create the regulatory framework, infrastructure and market incentives for the creation of well-paid, secure, healthy, satisfying environmentally friendly jobs with particular attention to appropriately meeting the needs of affected workers and their communities". It is therefore the responsibility of governments to scale up the transition to minimise the costs on the affected the communities. The fourth principle relates to social justice and a fair distribution of both costs and benefits. A just transition "furthers social justice and equity and minimizes social barriers to the implementation of climate policies by ensuring that the costs and benefits of these policies are evenly distributed, and that these policies address communities' current and future needs" (Aguinaga, 2016: n.p.). Consequently, failure to implement it "implies that the cost of moving towards sustainability will devolve wholly onto workers in targeted industries and their communities" (Canadian Labour Congress, 2000: 4), and that will certainly be an obstacle to effective and efficient fights against global warming. It is nevertheless important to mention that, despite the multiplicity of voices calling for its implementation, just transition remains a contested concept. 


\section{Just Transition: A Contested Concept}

Despite its common usage in official documents, the concept of just transition is not homogeneous. Even though all trade unions and climate justice movements advocate for just transition, they do not always agree on the actors and institutions to involve, or on the level or context of change to be implemented. Global unions demonstrate a great deal of variability in the interpretation of the strategy to be implemented (UNEP, 2008, 2011; ILO and UNEP, 2012; Räthzel and Uzzell, 2013; Stevis and Felli, 2015). Applying the affirmative and transformative approaches to remedying injustice developed by Nancy Fraser to JT, Gough (2010) devised a two-sided classification of the alternatives offered by JT thinkers. For Fraser $(1995,2005)$, there is an "affirmative" view that calls for the restoration of justice within the current world order configuration, and a "transformative" view according to which justice principles can be implemented only in the context of a completely transformed world and social order. When it comes to the specific context of a just transition, the affirmative view can be applied to the range of approaches that call for more equity within the parameters of the existing political economy, while transformative view refers to those that call for a radical change of the political economy (Gough, 2010). Rosemberg (2013) also sees the internal contradictions of JT defenders from a double perspective - those who defend green growth and those who advocate for no growth. The first group believes that the solution to the environmental/climate crisis lies in the reform of the market and its institutions, but still within the current market economy system. The advocates of this vision, also known as reformists, include the United Steelworkers in the United States (USA), ITUC, the CGTP, the European Trade Union Confederation (ETUC) and other union members in the context of the Portuguese climate jobs campaign. For them, "markets can be greened if the externalities of economic production and processes on the environment are priced" (Rosemberg, 2013: 22). The second group, often referred as radicals, challenges the first and calls for the need to think outside the box to "ensure that our societies will prosper and be more socially just in a resource-limited world" (Rosemberg, 2013: 24). For this second version of just transition (endorsed in the Portuguese campaign by Climáximo and other climate justice activists), there is no way for a dialogue with current institutions; they need to be confronted and forced to action through massive public contestations, marches and even civil disobedience. Stevis and Felli (2015: 12) conclude that this vision is more "confrontational (and less prone to advocating win-win solutions), because it rests on the assumption that the current crisis is being structured by an unequal distribution of wealth, property and power in capitalist society". Advocates of this approach go beyond struggles that simply push for job creation in a greened economy. They refuse to abide by market solutions and prefer to adopt a radical critique of capitalism (Barca, 2016), advocating a complete system change and not simple patching of the current system. Such radical socio-economic changes, in a changing environment context, require:

... an integrated approach to climate change, unemployment, and inequality, as well as a rejection of market mechanisms to solve these problems.... In this model the link between social justice and climate change is acknowledged, and the need for radical, structural change is emphasized (Cock, 2014: 24).

This radical approach is the one endorsed by system-changers such as the climate justice movement in general, including those involved in the Portuguese campaign. In fact, a close observation brings me to argue that varying interpretations of just transition are, in the Portuguese case, not just ideological or strategic differences but represent the different organisational bases of the two influential actors involved - unions and climate justice movement activists. In other words, the gap between unions and CJM activists, jointly involved in climate jobs campaigns, is still 
consistent. The first, motivated by some sort of political realism with regard to workers whose rights they stand for, defend a JT project within the current neo-liberal system through mechanisms of eco-efficiency, eco-modernisation and other technological solutions. The latter, holding the current system entirely responsible for the climate crisis and judging it completely incapable of leading the transition, poses system change as a non-negotiable preliminary step towards just transition. This second vision - also baptised the "social power approach to Just Transition" by Sweeney and Treat - not only rejects the current neo-liberal capitalist and green-growth models; their growth and profits imperatives calls for an

...energy democracy [that] entails three broad and strategic objectives: (1) resisting the agenda of large energy corporations, (2) reclaiming to the public sphere parts of the energy economy that have been privatized or marketized, and (3) restructuring the global energy system in order to massively scale-up renewable and low-carbon energy, aggressively implement energy conservation, ensure job creation and local wealth creation, and assert greater community and democratic control over the energy sector (Sweeney and Treat, 2018: 36).

\section{Insights from the Portuguese Climate Jobs Campaign}

Portugal faces both vulnerability to the climate crisis and increasing precarity of employment.

As far as the climate crisis is concerned, the country is highly "vulnerable to climate change impacts that result mainly from a decreasing annual precipitation, more intense extreme weather and climate events, particularly heat waves, droughts, and inundations associated with heavy precipitation events, and mean sea level rise" (Carvalho et al., 2014: 200). These phenomena threaten its forests, population, islands and coastal territories, and this in turn leads to high social and economic costs. Considering environmental vulnerabilities related to coastal zones, for example, it is important to mention that in Portugal "nearly two thirds of the population are concentrated in the littoral areas, whereas the interior is increasingly being abandoned in spite of investment efforts to stabilize the local population" (Figueiredo, Fidélis and Pires, 2002: 199); this concentration of the population in the coastal areas does not only increase the level of stress on the environment, but also and above all contributes to increasing the number of people exposed to environmental catastrophes related to coastal zones. Equally, if we take the forest sector, it is estimated that the country annually spends between 60 and 140 million Euros because of forest fires. So far, the peak in this expenditure was in 2005 with costs estimated at about 290 million Euros. Losses in the agriculture sector cannot be ignored. The 2012 drought, for example, had an estimated cost of 200 million Euros, with additional management and administrative costs of more than 250000 Euros (Agência Portuguesa do Ambiente 2017). Despite such vulnerability and the need for urgent action to halt the adverse effects of global warming, the country might not meet its reduction targets. In fact, the 2017 Portuguese National Inventory Report from the Portuguese environmental agency confirms an increase in national greenhouse gas emissions and states that "after the continuous decrease of national emissions verified since 2005, the emissions registered a significant growth in 2015, with an increase of 7.0\% compared to the 2014" (Agência Portuguesa do Ambiente, 2017: iv).

When it come to the labour situation Portugal, from the official perspective is usually said to be among the European countries with an average unemployment rate (European Union, 2017). Nevertheless, such apparent decrease in unemployment can be due to four reasons: i) the growing number of young people staying longer in school (United Nations, 2015): ii) the number of people leaving the country to look for greener pastures (Martins, 2017); iii) the inaccuracy of labour data 
that do not take into consideration those jobseekers who are removed from the records of the national employment agency (Instituto de emprego) because they do not fulfil the conditions or cannot go through the complexity of Portuguese bureaucracies (Kenfack, 2018b); iv) the predominance of under-employment and precarious work (Martins, 2018). The growth of the last factor, precarious work, is manifested in three basic ways. First, there is the extended use of shortterm contracts and the freelance-worker payment receipts (recibos verdes) both in the private and public sector. Second is the use of research fellowships (bolsas) to recruit workers for administrative and maintenance tasks (in universities, research laboratories and in the public administration), with many working for decades without any social security coverage, retirement plan or permanent contracts. The third refers to the low salaries, compared to the life standard. In this regard, an employment survey carried out by CGTP (2016) indicates that eight out of ten new contracts since 2013 are precarious. In this context of double crisis, Portuguese climate jobs campaigners are calling for a solution that articulates the protection of the environment and the interests of workers and their communities, as well as social justice demands, into a single struggle for a just transition to a post-carbon society. Nevertheless, it is important to mention that, despite the unifying purpose of cumulatively tackling social, labour and climate justice, and the coalition-building power such unifying purpose and networking play in social mobilisations (Schmalz et al., 2018), the Portuguese climate jobs campaign still faces a substantial internal divisive challenge between non-union members who mostly endorse the transformative vision and unionists who support the affirmative vision of a just transition.

The campaign was officially launched during the labour march organised by CGTP on 1 May 2016, simultaneously in Lisbon under the leadership of the Lisbon-based climate justice movement Climáximo and Porto under the leadership of the Porto-based climate justice movement Colectivo Climá. Paradoxically, there was very limited involvement of trade unions and labour movements. In fact, even though campaigners were offered a space to be part of the labour march on that day in both cities, it should be noted that this came after long negotiations with unions involved in the march. Agreements were reached not because of any institutional dynamics within unions and labour movements, but instead thanks to the influential role played by some individual union members who sympathised with the campaign. In a context where trade union struggles are still dominated by demands for better wages, for a reduction in working hours, and for more uniform working hours between public and private sectors workers - a situation confirmed by all the union leaders I talked with - the tradition of fighting for environmental issues is still at the initial stage, and unions are not yet really involved in the climate justice fight. Moreover, as a CGTP staff member confessed, "domains of action are clearly determined in Portugal and, respecting that social division of responsibilities, CGTP and its member unions have historically limited themselves to defending workers' concerns, therefore allowing other social movements to defend non-workplace-related concerns". It is therefore through its official association and participation in the climate jobs campaign in 2016 that the confederation started to fully integrate social struggles that are not limited to workplace concerns. This is unlike the UK context where the initiative of the campaign came from a group of unionists, or South Africa where we can witness a strong engagement of unions even though the initiative came from non-union entities (Kenfack, 2018a).

The engagement of Portuguese unions in the national climate jobs campaign is still very limited, sporadic and non-institutionalised. The participation of some unions in the campaign is the result of individual union members concerned with climate justice issues who are trying to play the double role of ensuring union presence in the campaign, and motivating their unions to consider and integrate the environment. In that context, Climáximo took the initiative of building a network of climate justice, labour and environmental movements as well as trade unions around 
the climate jobs campaign. This is because, as a campaigner from the activist group stated "the climate jobs campaign ... can be easily explained and easily understood, and it brings new sets of alliances and new possibilities of alliances, and it is going to be the biggest environmental issue in Portugal since the 70s". Even though the initiative of the campaign came from Climáximo, other entities such as the Porto-based climate justice activist group Colectivo Climá, GAIA, the labour movement Precarios Inflexiveis, and the CGTP participated in its preparation and implementation right from the beginning. Nevertheless, if the two above-mentioned activist groups (mostly made up of university students) and GAIA were directly and institutionally involved in the day-to-day preparation of the campaign, we cannot say the same thing about the two other campaign partners. In fact, the participation of Precarios Inflexiveis (a non-union, legalised social movement engaged in the fight for the protection of workers' rights and jobs) was guaranteed by an individual member who, motivated by her personal interest in the protection of the environment, dedicated herself to pushing forward the climate jobs agenda within the movement. As far as CGTP is concerned, it should be noted that within the confederation there is a core group of three members in charge of environmental and sustainable development matters. Two of those members, motivated by their personal climate sensitivity and engagement, are the ones trying to push forward the environmental, climate justice and just transition agenda within CGTP and its union members. In other words, apart from officially supporting the campaign by issuing declarations and offering space for campaigners to be part of the labour march celebrations, or inviting campaigners to give climate talks to unionists from time to time, the confederation does not really participate in the outdoor activities of the campaign, at least not from an institutional standpoint. In view of this, the concern to be raised is that, if the two members of the core team pushing forward the agenda are no longer there, there might be a drop-off of the campaign on the part of the confederation, since its current support has no institutional grounding.

After the official launch, other movements decided to officially join the campaign. Among them we have the faith-inspired movement Juventude Operária Católica, local anti-exploration movements such Alentejo Livre Petroleo and Peniche Livre de Petroleo, and trade unions such as the teachers' union of the Lisbon region (Sindicato dos Professores da Grande Lisboa, SPGL) and the teachers' trade union of the north (Sindicato de Professores do Norte, SPN). In the specific case of teachers' unions, an interesting fact is the divergence between the official positions of unions, generally in line with the affirmative version of just transition as supported by CGTP (of which they are members), and the individual positions of most teachers involved in the campaign, most of them activists, who stand for the transformative approach. Moreover, even though the SPGL officially supports the campaign, during one of the meetings with their representatives I could assess the level of internal divisions this support generates. On this matter, union members are divided into two groups - those who think priority should be given to the protection of the environment and that fossil fuel should completely be phased out, and those who believe the union should neither support the campaign nor become involved in any other anti-extractive and antiexploration campaign. For this second group, there is a belief that their "parents, relatives and friends who work in those sectors will be victims of the transition and there will surely be no concrete measures to address their situations". This tension suggests that even though there is a full conscience, among teachers and unions, that a just transition should be urgently initiated, pragmatic reasons related to the fear of uncompensated job losses generate and nurture reluctances.

One of the main activities of the campaign has been to carry out research to support the demands. According to the declarations of a GAIA member and Climáximo activist, the aim of such research is:

Global Labour Journal, 2019, 10(3), Page 232 
...to have numbers about finances, numbers about emissions cuts, and numbers about jobs in Portugal. ... One of the ideas of the editorial group is to produce short articles or essays along the road to reach out, like to explain some aspects of the campaign, but those will be like complementary work that is surrounding the scientific work. The end result will be numbers. The presentation of it can be more popular than an Excel sheet, but at the end what we are looking for are solid numbers, rigid numbers, in somehow sophisticated language.

To obtain those numbers, campaigners rely on the assistance of some activists, academics and unionists. The research, which is still ongoing, has nevertheless already produced information about some key sectors requiring a transition to a low-carbon mode of operation. To be considered a climate job, according to the campaign's view, four conditions must be met. Basically, they must be:

1) New jobs (not recycled and rebranded current existing jobs). 2) Jobs in the public sector. 3) Jobs with the objective of cutting GHG (securing transition from polluting sectors into clean and sustainable ones). 4) Jobs that guarantee the requalification of workers currently working in polluting sectors (Eden, 2017).

The campaign estimates that by creating 100000 new jobs, Portugal can cut its greenhouse gas emissions by 60-70 per cent in fifteen years (Climáximo, 2017). So far, analyses have been done in sectors such as public transport, water, forestry and energy transition.

Beside the research component, climate justice training is often organised for labour and trade unions that are more and more expressing their need to be trained on the issue. Primary and secondary schools also often solicit campaigners to come and give talks to pupils on climate issues and possible solutions; in the same vein university student groups often invite campaigners to have discussion sessions at universities with their members. In addition, campaigners often organise movie sessions followed by public debates around previously selected and advertised climate justice documentaries in important cities. Beside that, they continue to build a social network around the climate jobs campaign, by approaching and convincing new movements and unions to join the campaign. In this regard, campaigners often use the same strategy in approaching both union members and members of well-established organisations and social movement in an informal way to work with them towards pushing forward the climate justice and JT agendas within their organisations. Individuals who, based on their climate and environmental sensitivity, are contacted following the recommendations of climate justice activists, unionists or current sympathisers of the campaign, are first instructed about climate change, climate justice and climate jobs. After such briefing, they are encouraged to relay those concerns within their organisations, and in some cases they are used as bridges through which campaigners formally contact organisations by sending invitations to participate to the campaign's activities. By so doing, campaigners try to build a critical mass of organised bodies for the campaign, while relying and counting on the continuous underground support and action of a core group of convinced members belonging to the partner organisations. I argue that this is a strategic and well-calculated approach because Climáximo, which is the mastermind organisation behind the campaign, is a relatively young and non-legalised social movement, formed in 2015 on the eve of the Paris Conference of the Parties. It is mostly made up of a small group of students and young people with limited resources. Since Climáximo does not have legal legitimacy to contact and work with formal organisations, approaching them through their internal members is therefore instrumental in gaining their support and adherence to the campaign. 
Moreover, campaigners often organise climate marches when there is an important international day such as forest day, biodiversity day, an event such the Conference of the Parties (COP), or in solidarity with climate justice events or marches happening in other parts of the world. Other activities of the Portuguese climate jobs campaigners include organising and participating in outdoor mobilisations for the protection of forests and the reform of forest policies, participating in struggles against oil exploration and exploitation in Portugal, particularly along the Alentejo coast, and participating in social struggles against austerity and precarious work in Portugal. One of the key activities of campaigners has been the organisation of "toxic tours". During those tours, campaigners often go to companies such as Partex, Repsol, Volkswagen, Barclays, Deutsche Bank and the Gulbenkian Foundation, among others. Those companies are chosen because of their oil exploitation activities (Partex and Repsol), their huge investments in oil exploration and mining around the world (Barclays and Deutsche Bank), or the greenwashing and funding of a number of research projects on the possibilities of commodification of marine resources (Gulbenkian Foundation). During the tours, public presentations on the environmentally dangerous activities of each of those entities are made and the general public can ask for clarification. This is usually preceded or followed by the distribution of pamphlets of the dangers of climate change, the responsibilities of financial, mining and fossil fuel corporations, and the limited actions of governments.

This broad involvement in various activities goes beyond narrowly focused labour justice demands as envisaged by unions and labour movements, and narrowly focused environmental or social justice demands as claimed by environmental movements and social movements respectively. This stance comes from the fact that, according to campaigners, for climate justice to become real in Portugal it is important to relate it to social and labour justice. As such, as was stated during one of the meetings of the activist group, "the fight against injustices (precarious work, social inequalities, jobs scarcity, exploitation of poor people's ecosystems, and petrol exploration among others) will lead to better respect of the environment and limitation in GHG emissions in the country". To cumulatively tackle climate and social justice in a successful way, campaigners advocate the creation of climate jobs that respect four basic principles, namely: 1) newness of the jobs; 2) prioritisation of current workers in the polluting sector when filling job positions created in the context of just transition; 3) cutting of greenhouse gas emissions; and 4) exclusive leadership of the public sector.

The divisive potential of the two visions of a just transition is justified through the positions endorsed by Climáximo and CGTP, the two most significant actors of the campaign, with the greatest mobilisation capacities. When it comes to the actors involved, Climáximo believes that just transition as well as the jobs created should be left in the exclusive hands of governments and their agencies. In other words, as one of the activists expressing the position of Climáximo stated, "Climate jobs will have to be jobs created exclusively by the government". CGTP has a different view. In fact, for the workers' confederation, the "conditions for green and decent jobs can exist in any sector of activity, service, industry, agriculture or fishing! Green businesses and jobs are those that respect all sustainable development principles" (Casula, 2016). In this regard, while Climáximo advocates for jobs that will be completely new and exclusively in the public sector, CGTP is motivated by the growth imperative, and thinks that they may also be rebranded jobs (current jobs adapted to the requirements of the green economy), under the public as well as the private sectors as long as they respect sustainable development principles. On the other hand, as far as the context of the transition is concerned, Climáximo endorses a more radical, anti-capitalist and systemchanger view following transformative and social power approaches, while CGTP defends a more reformist, green economy/capitalist, and eco-moderniser vision as portrayed by affirmative and 
social dialogue approaches. According to a Climáximo member, the activist group

...basically adopted the climate space manifesto. The climate space is a space created in the World Social Forum on climate change. The manifesto is clear enough to specify that we are anti-capitalist and that we have certain choices to make, and are not going to base ourselves on lobbies' interests.

Contrary to such a radical position, the following statement of a representative of CGTP during the second national climate justice meeting reveals the flexible position of the workers' confederation:

We are all here struggling for climate justice and for climate jobs. We are all demanding divestment from fossil fuels and investment in clean energy, and we are all convinced that this is the way to go. Nonetheless, I would like to point out that we, as a trade union confederation have some characteristics that none of the movements in the hall has. We must defend the environment, yes! But we also have to defend workers and their jobs, and that is where it becomes complex for us. If a fossil-fuel-dependent company asks us whether to continue operating or to divest from fossil fuels and stop its activities, for all of you the choice will be obvious. For us that will not be so easy to decide and to reply.

In short we can say that, following Sweeney and Treat's (2018) social power approach, for Climáximo a just transition can occur only in the context of a completely post-capitalist society. CGTP, on the other hand, following the social dialogue approach defended by ITUC and other mainstream international unions, believes that a reformed and humanised capitalism can lead us to the paths of just transition. In other words, by defending that green jobs should be created in the context of the green economy, CGTP goes in line with the ecological modernisers' position that is built on the social dialogue approach. On its end, Climáximo defends climate jobs being created in the context of a completely new and post-capitalist system, following the radical demands of system-changers generally endorsed by climate justice movements and radical labour movements and unions.

\section{Conclusion}

To conclude, we can say that the divisive conception between transformative and affirmative views of just transition appears to be a consistent approach in evaluating the internal conflicts among actors involved in struggles to integrate labour, social justice and climate justice matters in the current global warming regime, and to foster the shift to a post-fossil-fuel socio-environmental development path. In fact,

...with growing awareness of the climate crisis and its far-reaching impacts, the labor movement [supported by new social movements] is again calling for a Just Transition to ensure that workers will have a voice in shaping the changes necessary to move away from fossil fuels (Dougherty, 2016: n.p.).

It is in this regard that, to force global leaders to act, labour and climate justice movements in the past years have been organising joint mobilisations around the world. Climate jobs campaigns can be situated in this new wave of alliances and can be characterised as red-green-social alliance movements demanding just transition to a low-carbon economy in specific national contexts. The case of Portugal helps in understanding that the emergence of the campaign was made possible by the co-existence of two crises: the climate crisis and the employment crisis. A group of Portugal- 
based activists were convinced that the future and habitability of the planet are quite important and cannot be left in the hands of the current economic system (Eden, 2017). To address both crises synergistically, they decided to launch a campaign, even with limited involvement from unions, that demands proper solutions to the climate crisis while putting workers, their jobs and their livelihoods at the centre of preoccupation in Portugal. After its official launch on 1 May 2016, campaigners continued to participate in many outdoor and training activities, with the aim of building a strong climate justice consciousness and a strong climate justice network to push for just transition at the national level. Nevertheless, the campaign continues to face challenges, the most important of which are the contrasting views among the actors to involvement in the just transition, and the antagonistic perspectives on the context in which a transition to a post-carbon economy should occur. From this perspective, the Portuguese campaign as a paradigmatic case demonstrates that just transition, even though a unifying project, is a contested concept. In fact, the reality of its implementation in Portugal faces an important division between defenders of the soft or affirmative version of just transition endorsed by CGTP, and the defenders of the radical or transformative version endorsed by Climáximo. In other words, we can say that even though one of the most important aspects of the Portuguese climate jobs campaign is that it helps render an account of the JT divide between unionists and non-union activists, it nevertheless teaches that such a divide is not insurmountable. The reality shows that the two categories of actors continue to work together in the struggle for energy transition and the creation of climate jobs. In fact, despite all its internal division and contradictions, the Portuguese campaign, by encouraging organisations that historically have never worked together to overcome their cleavages and divergent interests and start engaging in a common struggle for the protection of the environment and the creation of climate jobs, shows that it is possible to overcome divides in social struggles and to fight for a common purpose. Equally, by carrying out research on sectorial and quantified climate and environmentally friendly jobs that, in the context of just transition, can cumulatively help protect the environment and the interests of workers, the campaign attempts to demonstrate that the jobs-versus-environment contradiction can be overcome. In other words, we can save the environment without necessarily destroying jobs.

\section{REFERENCES}

Agência Portuguesa do Ambiente (2015) Estratégia Nacional de Adaptação às Alterações Climáticas. Lisboa: Agência Portuguesa do Ambiente.

Aguinaga, E. (2016) Labor Day and Just Transition. http://www.gcclp.org/single-post/2016/05/01/ LaborDay-Just-Transition (accessed 10 September 2018).

Arowolo, S. (2015) COP 21: Towards an Inclusive Climate Negotiation in Paris. http://www.csag.uct.ac.za/ 2015/07/17/cop=21-towards-an-inclusive-climate-negotiation-in-paris (accessed 18 September 2018).

Barbier, E.B. (2010) A Global Green New Deal: Retbinking the Economic Recovery. New York: Cambridge University Press.

Barca, S. (2015) Greening the Job: Trade Unions, Climate Change and the Political Ecology of Labour. In The International Handbook of Political Ecology, edited by R.L. Bryant. Cheltenham and Northampton: Edward Elgar Publishing.

Barca, S. (2016) Labor in the Age of Climate Change. https://www.jacobinmag.com/2016/03/climate-laborjust-transition-green-jobs (accessed 20 February 2018).

Bill, A., R. Welters, J. Rutovitz, G. Evans and W. Mitchell (2008) A Just Transition to a Renewable Energy Economy in the Hunter Region, Australia. Newcastle: Centre of Full Employment and Equity. 
Burawoy, M. (1998) The Extended Case Method. Sociological Theory, 16(1): 4--33.

Canadian Labour Congress (CLC) (2000) Just Transition for Workers during Environmental Change. Ottawa: Canadian Labour Congress.

Carvalho, A., L. Schmidt, F.D. Santos and A. Delicado (2014) Climate Change Research and Policy in Portugal. Wiley Interdisciplinary Reviews: Climate Change, 5(2): 199-217.

Casula, G. (2016) A transição justa como solução para criação de emprego. http://www.cgtp.pt/images/images/2016/11/TransicaoJusta.pdf (accessed 28 September 2019).

Climáximo (2017) 100000 Climate Jobs in Portugal. http://www.empregos-clima.pt/100-000-climate-jobsportugal/ (accessed 18 September 2017).

Confederação Geral dos Trabalhadores Portugueses (CGTP) (2016) Por uma politica de mais e melhor emprego, urge lutar contra a precariedade. http://www.cgtp.pt/informacao/comunicacao-sindical/9774-por-umapolitica-de-mais-e-melhor-emprego-urge-lutar-contra-a-precariedade (accessed 18 September 2017).

Cock, J. (2014) The "Green Economy": A Just and Sustainable Development Path or a "Wolf in Sheep's Clothing"? Global Labour Journal, 5(1): 23-44.

Dougherty L. (2016) The Roots and Shoots of Just Transition. http://breakfreepnw.org/roots-shoots-justtransition/ (accessed 9 September 2019).

Eden, S. (2017) Descarbonizar a Economia Portuguesa Criando Milhares de Empregos. http://www.empregosclima.pt/descarbonizar-economia-portuguesa-criando-milhares-de-empregos-sinan-eden-climaximo/ (accessed 5 June 2018).

European Union (2017) Unemployment Statistics. http://ec.europa.eu/eurostat/statistics-explained/ index.php/Unemployment statistics (accessed 12 June 2018).

Figueiredo E., T. Fidélis and A.R. Pires (2002) Grassroots Environmental Action in Portugal (1974-1994). In Environmental Politics in Southern Europe. Actors, Institution and Discourses in a Europeanizing Society, edited by K. Eder and M. Kousis. Berlin: Springer Science \& Business Media.

Fraser, N. (1995) From Redistribution to Recognition? Dilemmas of Justice in a "Post-Socialist" Age. New Left Review, I(212): 68-93.

Fraser, N. (2005) Reframing Justice in a Globalizing World. New Left Review, II(36): 69-88.

Gobo, G. (2001) Descrivere il Mondo. Roma: Carocci.

Gough, J. (2010) Workers' Strategies to Secure Jobs, Their Uses of Scale, and Competing Economic Moralities: Rethinking the "Geography of Justice". Political Geography, 29: 130-139.

Grasswick, H. (2006) Feminist Social Epistemology. In Stanford Encyclopedia of Philosophy (Fall 2018 Edition), edited by E.N. Zalta, U. Nodelman, C. Allen and R.L. Anderson. https://plato.stanford.edu/archives/ fall2018/entries/feminist-social-epistemology/ (accessed 8 September 2018).

Harding, S. (1995) "Strong Objectivity": A Response to the New Objectivity Question. Synthese, 104(3): 331-349.

Huber, M. (2016) The Carbon Tax is Doomed: The Burden of Market-based Climate Change Solutions will Fall on Workers. We Need Strong State Intervention. https://www.jacobinmag.com/2016/10/oil-fossil-fuelclimate-cap-trade-tax-renewables $/$ (accessed 28 January 2018).

International Labour Organization (ILO) and United Nations Environment Programme (UNEP) (2012) Working Towards Sustainable Development: Opportunities for Decent Work and Social Inclusion in a Green Economy. Geneva: International Labour Office.

International Trade Union Confederation (ITUC) (2009) Trade Unions and Climate Change, Equity, Justice \& Solidarity in the Fight against Climate Change. https://www.ituc-csi.org/IMG/pdf/climat_EN Final.pdf (accessed 10 April 2018).

International Trade Union Confederation (ITUC) (2010) Resolution on Combating Climate Change through Sustainable Development and Just Transition. https://www.ituc-csi.org/IMG/pdf/2CO 10 Sustainable development and Climate Change 03-10-2.pdf (accessed 9 August 2018). 
Just Transition Centre (2017) Just Transition: A Report for the OECD. https://www.oecd.org/environment/ cc/g20-climate/collapsecontents/Just-Transition-Centre-report-just-transition.pdf (accessed 16 June 2017).

Kenfack, C.E. (2018a) Changing Environment, Just Transition and Jobs Creation: Perspectives from the South. Buenos Aires: CLACSO.

Kenfack, C.E. (2018b) Climate Politics from Below. The Climate Jobs Campaign as a Social Movement Response to Global Climate Governance. Unpublished doctoral thesis, University of Coimbra, 5 April 2018.

Martins, A.N. (2017) Taxa de desemprego cai para 10,5\% em novembro. http://observador.pt/2017/01/06/taxade-desemprego-cai-para-105-em-novembro/ (accessed 22 January 2018).

Martins, R. (2018) Trabalhadores a recibos verdes no Estado aumentam 14,6\%. https://www.publico.pt/2018/07/ 10/economia/noticia/trabalhadores-a-recibos-verdes-no-estado-aumentam-146-1837428 (accessed 11 July 2018).

O'Driscoll, D. (2011) Airbrushing in Just Transition. https://notesfrombelow.wordpress.com/2011/05/19/ airbrushing-in-just-transition/\# edn2 (accessed 10 November 2017).

Olsen, L. (2010) Supporting a Just Transition: The Role of International Labour Standards. International Journal of Labour Research, 2(2): 293-318.

Paret, M. (2016) Towards a Precarity Agenda. Global Labour Journal, 7(2): 111-122.

Räthzel, N. and D. Uzzell (2013) Mending the Breach between Labour and Nature: A Case for Environmental Labour Studies. In Trade Unions in the Green Economy: Working for the Environment, edited by D. Uzzell and N. Räthzel. London: Earthscan.

Roberts, D. (2010) Prioritizing Climate Change Adaptation and Local Level Resilience in Durban, South Africa. Environment and Urbanization, 22(2): 397-413.

Robins, N., V. Brunsting and D. Wood (2018) Investing in a Just Transition: Why Investors Need to Integrate a Social Dimension into their Climate Strategies and How They Could Take Action. Policy Insight. http://www.lse.ac.uk/GranthamInstitute/wp-content/uploads/2018/06/Robins-et-al_Investing-in-aJust-Transition.pdf (accessed 9 September 2019).

Rosemberg, A. (2013) Developing Global Environmental Union Policies through the International Trade Union Confederation. In Trade Unions in the Green Economy: Working for the Environment, edited by D. Uzzell and N. Räthzel. London: Earthscan.

Schmalz, S., C. Ludwig and E. Webster (2018) The Power Resources Approach: Developments and Challenges. Global Labour Journal, 9(2): 113-134.

Stevis, D. and R. Felli (2015) Global Labour Unions and Just Transition to a Green Economy. International Environmental Agreements: Politics, Law and Economics, 15(1): 29-43.

Sweeney, S. and J. Treat (2018) Trade Unions and Just Transition. The Search for a Transformative Politics. Working Paper $\mathrm{N}^{\circ}$ 11. New York: Trade Unions for Energy Democracy (TUED). http://www.rosaluxnyc.org/wp-content/files mf/tuedworkingpaper11 web.pdf (accessed 22 May 2019).

Trades Union Congress (TUC) (2008) A Green and Fair Future: For a Just Transition to a Low Carbon Economy. TUC Pamphlet 3. https://www.tuc.org.uk/sites/default/files/documents/greenfuture.pdf (accessed 9 September 2019).

United Nations Environment Programme (UNEP) (2008) Payments for Ecosystem Services Getting Started: A Primer. $\quad$ https://wedocs.unep.org/bitstream/handle/20.500.11822/9150/payment ecosystem.pdf ? sequence $=1$ \&is Allowed $=\mathrm{y}$ (accessed 9 September 9 2019).

United Nations Environment Programme (UNEP) (2011) Towards a Green Economy: Pathways to Sustainable Development and Poverty Eradication: A Synthesis for Policy Makers. https://sustainabledevelopment.un.org/ content/documents/126GER synthesis en.pdf (accessed 9 September 2019). 
United Nations Framework Convention on Climate Change (UNFCCC) (2009) FCCC/AWGLCA/2009/8. Negotiating Text. Document prepared by the Ad Hoc Working Group on Long-term Cooperative Action under the Convention (AWG-LCA). http://unfccc.int/resource/docs/ 2009/awglca6/eng/08.pdf (accessed 22 August 2018).

United Nations (2015) The Millennium Development Goals Report 2015. New York: United Nations.

Van Velsen, J. (1967) The Extended-case Method and Situational Analysis. In The Craft of Social Anthropology, edited by A.L. Epstein. London: Tavistock.

Webster, E. (2018) Review of: Vishwas Satgar (ed.) The Climate Crisis: South African and Global Democratic Eco-socialist Alternatives. Global Labour Joumal, 9(2): 234-238.

\section{ACKNOWLEDGMENTS}

We thank Dr. Stefania Barca and Dr. Emanuele Leonardi for their comments, critiques and guidance. Your different inputs greatly improved this article. Our gratitude also goes to the referees and editors of this piece.

\section{BIOGRAPHICAL NOTE}

CHRISLAin ERIC KENFACK is a Killam Postdoctoral Fellow in the Department of Political Science at the University of Alberta. He obtained his $\mathrm{PhD}$ in Political Science and Sociology from the University of Coimbra, Portugal, in 2018. His current research focuses on global climate governance, climate justice and climate activism, environmental labour studies, indigenous and faith-based environmentalism in Alberta, social cohesion environmentalism, and just transition. [Email: kenfack@,ualberta.ca] 